\title{
The Effectiveness of Using Serious Games to Improve Physics Learning Outcomes in Light Concept
}

\author{
Rudi Haryadi ${ }^{1, a)}$, Heni Pujiastuti ${ }^{2, b)}$ \\ ${ }^{1}$ Pendidikan Fisika, Universitas Sultan Ageng Tirtayasa, Serang 42111, Indonesia \\ ${ }^{2}$ Pendidikan Matematika, Universitas Sultan Ageng Tirtayasa, Serang 42111, Indonesia \\ 凶: a)rudiharyadi@untirta.ac.id, b)henipujiastuti@untirta.ac.id
}

\begin{abstract}
The purpose of this study was to determine the results of the use of serious games in physics learning in light material at Serang 6 Public High School. The research design used was the PreTest Randomized Control Group Post-Test Design. The population of the study was all of the eleventh grade students' of Serang SMA 6 which numbered six classes. The study sample consisted of one experimental class (XI MIPA 1) and one control class (XI MIPA 2). The results showed that the application of physics learning used a serious game on light material in class XI of Serang 6 High School which took place very well and had a positive effect on student learning outcomes. In addition, the students' response to the application of physics learning using the serious game was very good. The $\mathrm{N}$-gain result shows that the use of the serious game is 0.89 .
\end{abstract}

Keywords: serious game, learning outcomes, the concept of light

\section{INTRODUCTION}

Learning outcomes are values that students have as abilities received after carrying out the class's learning process (Shepherd \& van de Sande, 2014; Young, Moore, \& Ibrahim 2019). After teaching and learning activities end, the teacher will evaluate the students through physics concepts learned, which then students get the final grade or called learning outcomes (Haryadi \& Pujiastuti 2019a). Learning outcomes have an essential role in the learning process (Koponen \& Huttunen 2013). The main goal of learning activities is good learning outcomes (Merlone, Panchuk, \& Geert 2019). Learning outcomes measure students' conceptual abilities in receiving material (Pujiastuti \& Haryadi 2020).

Mastery of the material or essential competencies students must have through an evaluation conducted by the teacher at the end of learning (Haryadi \& Pujiastuti 2020a). No other main goal of teaching and learning activities is to get good learning outcomes (Berge 2016). With good learning outcomes, the teacher successfully learns (He, Han, \& Dezert 2019; Steins, Behravan, \& Behnke, 2020). Learning outcomes are significant benchmarks in the last learning activity (Kurniawati 2018). To obtain a good learning outcome, students must learn a lot to master the teacher's concepts (Ningrum \& Indrasari 2019). With a lot of learning, students will gain experience and understanding of new ideas due to a process that has been done (Diana, Khaldun, $\&$ Nur 2019). Learning is seen from a process or teaching and learning activities that are memorized, but learning students can increase their knowledge (Astra \& Budi 2018). Education is a process of interaction between the individual and the surrounding environment that will produce changes that are good for the individual himself, such as cognitive, affective, and psychomotor aspects (Malva, Leijen, \& Baucal 2020; Putnik et al. 2019).

Teaching and learning activities will produce concepts as indicators to determine student learning outcomes (Coninck, Walker, Dotger, \& Vanderlinde 2020). The concept of learning outcomes can be 
interpreted as a person's ability obtained through the learning process until learning is completed according to the teacher's learning design (Fischer \& Hänze 2020). Learning outcomes result from finding and transferring knowledge to make students know and solve their immediate environment (Dong, 2020). Learning outcomes obtained will make it easier for students to deal with problems in everyday life (Merlone et al. 2019). Learning outcomes focus not only on the change from knowing to knowing but also on students 'self-attitudes for the better and the development of students' lives. Learning outcomes can be seen from three aspects: cognitive, affective and psychomotor (Haryadi \& Pujiastuti 2019b).

Based on the above problems, to achieve the learning objectives, the teacher must make a learning innovation that is fun for students. Appropriate learning innovations are used in achieving optimal learning outcomes and conducive student conditions, which will significantly assist the implementation of useful, joyful, and educative teaching and learning activities. Currently, what will be used as a learning model that is used is the use of serious games (Kafai 2018).

A serious game is a learning model or approach to get good learning outcomes using educational games. In this case, games educate students so that learning activities are more enjoyable (Kayali et al. 2016). Furthermore, serious games are also useful for students to practice limbs' skills and strengthen the physical body (Sterkenburg \& Vacaru 2018). The next benefit is developing the child's personality and bringing the relationship between the teacher and other students closer (Suttie et al. 2012). Several other researchers revealed that a serious game is an educational game designed by teachers to increase student stimulus in solving existing problems (Lawrence, Garber, Eva, \& Una 2018). A serious game can also be a computer game whose design can be used in education (Khaled \& Vasalou 2014). Thus, the serious game is used as a learning medium for teaching and learning activities (Madani, Pierce, \& Mirchi 2017).

A serious game is a learning medium whose use can solve a problem (Maganty, Ilyas, Zhang, \& Sharma 2017). A serious game can also be a software simulation as a learning medium that can improve learning outcomes (Bessarabova et al. 2016). Serious games have advantages as a medium of learning, one of which is a fun game to do, then don't make you bored, because it can be done with various variations (Moloney, Globa, Wang, \& Roetzel 2017). Serious games can make students active in teaching and learning activities. Serious games can be interactive directly (Pasin \& Giroux, 2011). Serious games can provide a real experience and can be repeated as many times as desired. Besides mistakes made during the learning process can also be corrected (Perini, Luglietti, Margoudi, Oliveira, $\&$ Taisch 2018).

In this case, the serious game does not have to be applied several times face to face, but only as a medium or a tool in the learning process (Radianti, Lazreg, \& Granmo 2015). Entering the digital world today, teachers and students must master the development of ICT (Information and Communication Technologies) based on serious games (Riemer \& Schrader 2015). The result of ICT can be utilized for teaching and learning activities, including learning physics (Haryadi \& Pujiastuti 2020a). In learning physics, the learning process's final goal is to improve learning outcomes (Haryadi \& Pujiastuti 2019a). To achieve learning outcomes that have been determined by graduation standards, it requires treatment in learning physics (Haryadi \& Pujiastuti 2020c).

Therefore the need for exciting learning media and can motivate students to be more active in learning physics. In this study, one of the innovative efforts made in teaching and learning activities is the use of serious games to improve physics learning outcomes in the concept of light. Using serious games is to enhance students' thinking skills and understand the language in physics concepts.

\section{RESEARCH METHODOLOGY}

The method used in this study is a quasi-experimental method with a Randomized Pretest-Posttest Control Group Design research design. This research was conducted by giving treatment to the experimental group and the control group as a comparison. This design consists of two groups, each given a pretest and posttest, which is then treated with a game-based severe learning model. The research design can be seen in FIGURE 1 below (Creswell 2013). 


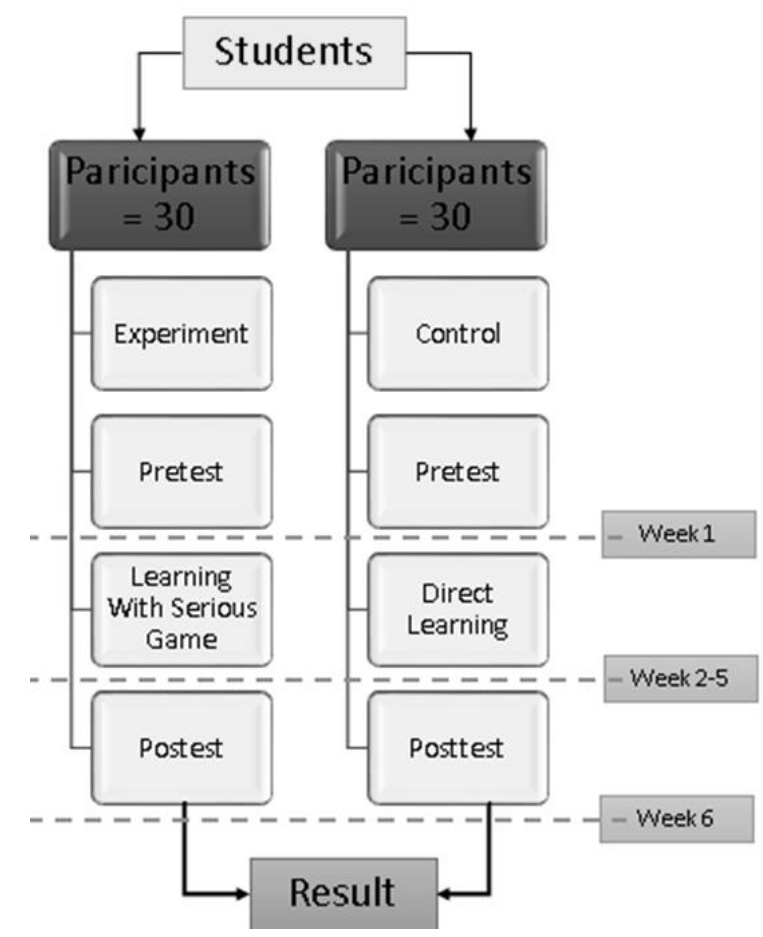

FIGURE 1. Randomized Pretest-Posttest Control Group Design

Furthermore, FIGURE 2 below shows the learning steps using the serious game.

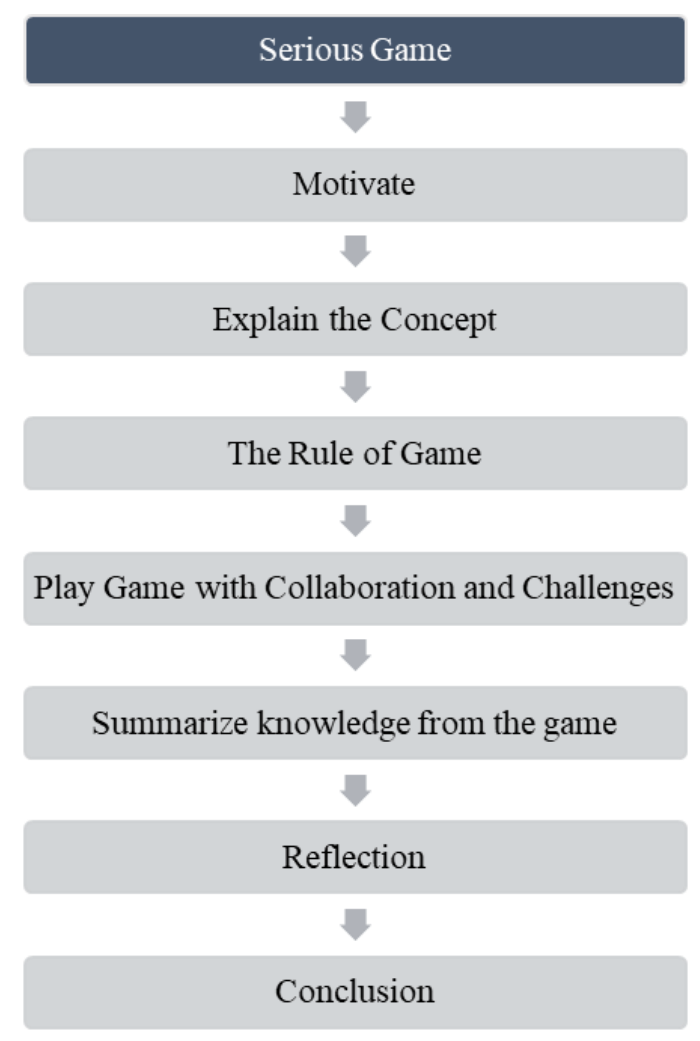

FIGURE 2. Design of Serious Game

This study's population was a class X MIA student in a secondary school in Serang in the academic year 2018/2019 with a total of 4 classes, with each class consisting of about 30 students. The sample from this study was selected using the random sampling class method to select two sample classes. 
Student learning outcomes were measured using an essay test instrument of 10 questions about the concept of light given before the pretest and after treatment in posttest learning. The assessment or determination of $\mathrm{N}$-gain can be seen in the formula below (Hake, 1998).

$$
\mathrm{N}-\mathrm{g}=\frac{\text { Score }_{\text {Posttest }}-\text { Score }_{\text {Pretest }}}{\text { Score }_{\text {Maximum }}-\text { Score }_{\text {Pretest }}}
$$

Then, to determine the criteria N-Gain, it can be seen in TABLE 1 below (Hake, 1998).

TABEL 1. N-Gain Classification

\begin{tabular}{lc}
\hline \multicolumn{1}{c}{ N-Gain } & Improvement Classification \\
\hline $\mathrm{g}>0.70$ & High \\
$0.30<\mathrm{g} \leq 0.70$ & Medium (enough) \\
$\mathrm{g} \leq 0.30$ & Low \\
\hline
\end{tabular}

\section{RESULTS AND DISCUSSION}

The average of the pretest and posttest scores increase in student learning outcomes will be calculated by calculating the NGain. Figure 3 shows the N-Gain data on learning outcomes by the experimental class and the control class students.

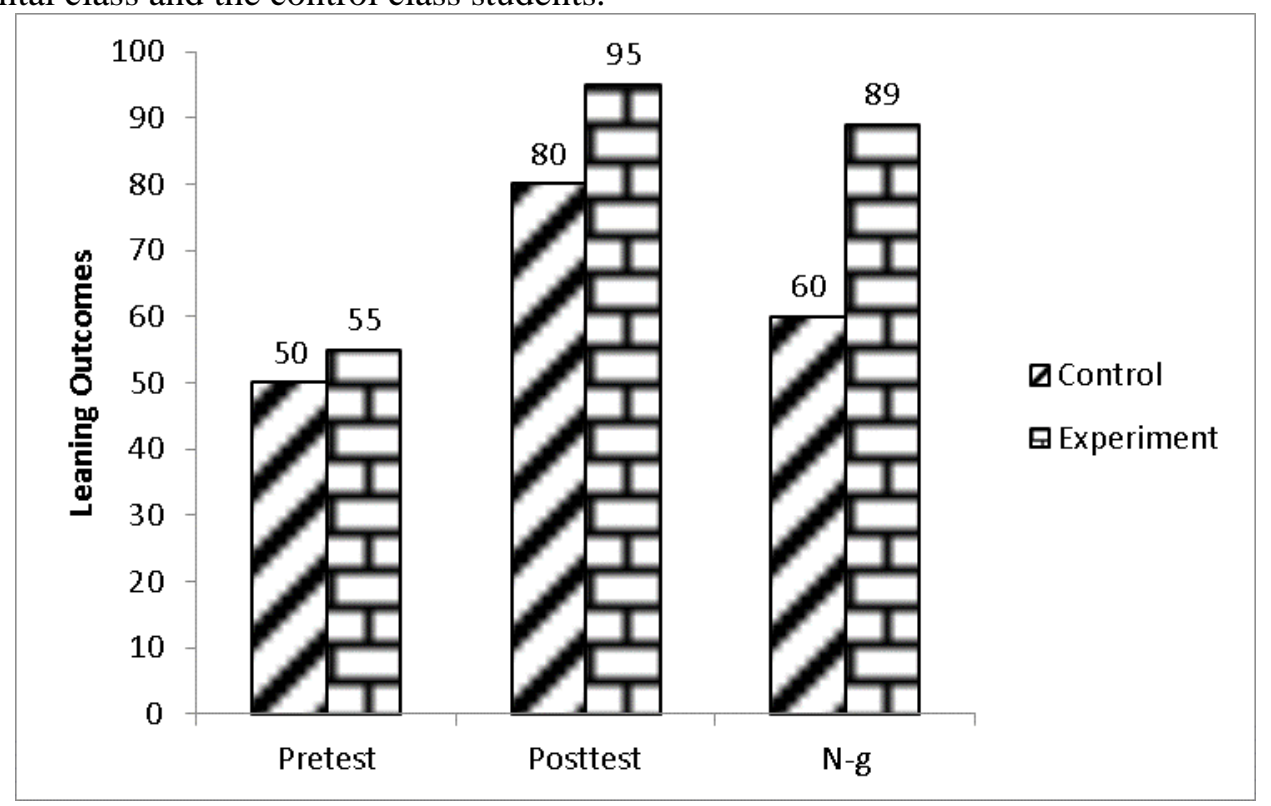

FIGURE 3. N-gain Physics Learning Outcomes as a whole

Based on the knowledge that the graph from FIGURE 3 shows, $\mathrm{N}$-gain's value from learning outcomes of classes that use serious games has a value of $89 \%$ or 0.89 and has a more significant influence than classes that do not use serious games, have a value of $60 \%$ or 0.6 . In detail, learning outcomes can be seen in FIGURE 4 below. 


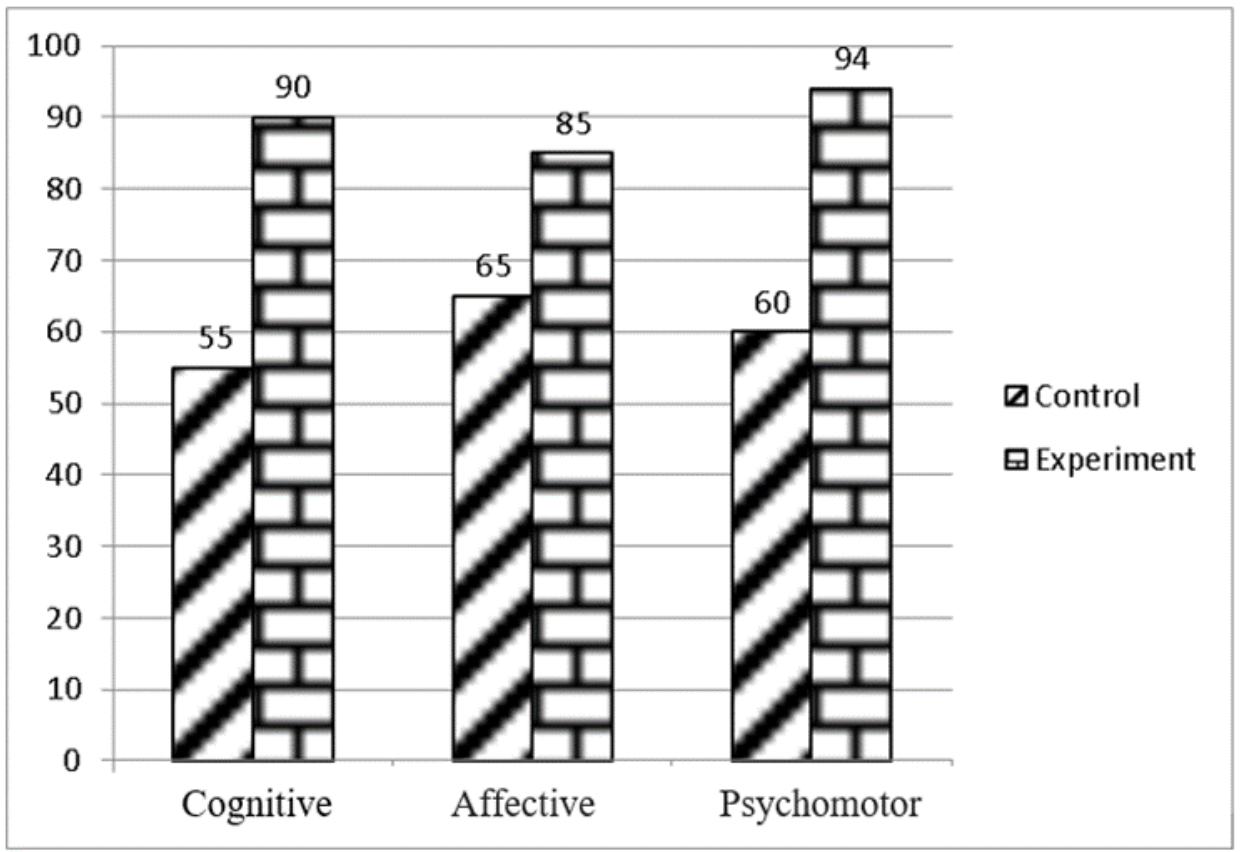

FIGURE 4. Physics Learning Outcomes Observed From the Cognitive, Affective and Psychomotor Aspects

Based on the graph in Figure 4, it can be seen that almost all aspects of learning outcomes in the experimental class have a higher N-gain percentage than the control class. So, it can be stated that increasing students' understanding of the material in every aspect of learning outcomes in the experimental class with the use of serious game-based learning is higher than in the control class with conventional learning. Based on the above data, it can be stated that students can get a better stimulus in remembering and exploring concepts that have been learned based on serious game learning. Students become motivated to participate actively in the learning process that helps them think about what knowledge they had before and then reflected on it with new experiences (Haryadi \& Pujiastuti, $2020 b$ ). Besides, students can directly observe changes in variables made for the concepts being learned. The serious game used is very interactive and makes students learn more variations now.

That way, students' learning not only memorizes but also learns to find self-concepts with the teacher's guidance so that learning becomes more meaningful (Pujiastuti, Utami, \& Haryadi, 2020). The serious gamification of this learning causes a significant increase in learning outcomes in the experimental class compared to the control class to make students more effective and efficient in conducting learning activities. With a serious game-based know, several students become more interested in doing the learning process because it can extract students' initial concepts through games and other visual displays related to the idea of light.

Through serious games, students can feel the concepts taught are contextual and in direct contact with their daily lives (Kafai, 2018). Besides, students' independence in learning to understand and understand their concepts can be facilitated by serious game-based learning so that students can repeat education and practicum done in free virtual classes anytime and anywhere without being bound by time and place.

Learning outcomes obtained are also high because students actively use their ability to solve problems when playing games directly. Meanwhile, when only using direct learning, students are only passive in understanding the material presented. Serious ICT-assisted games can be a solution if there is no equipment for practicum in schools. With the severe ICT-assisted game learning model, it can be said to be a complement to students in learning facilities to understand the concepts they learn through the findings they do independently (Moloney et al., 2017). A serious game can also be stated as one of the learning media that can improve student learning outcomes.

Serious games as learning media can make students play while learning. Students, in this case, using a computer or laptop media, feel very satisfied. These results are obtained from students through direct interviews. The satisfaction aspect of learning to use serious games here is pleasant and unpleasant 
feelings. These feelings can be positive when students appreciate themselves or the satisfaction that comes from within themselves. This level of student satisfaction will benefit the learning outcomes achieved. The results of the level of student satisfaction using serious games can be seen in Figure 5 below.

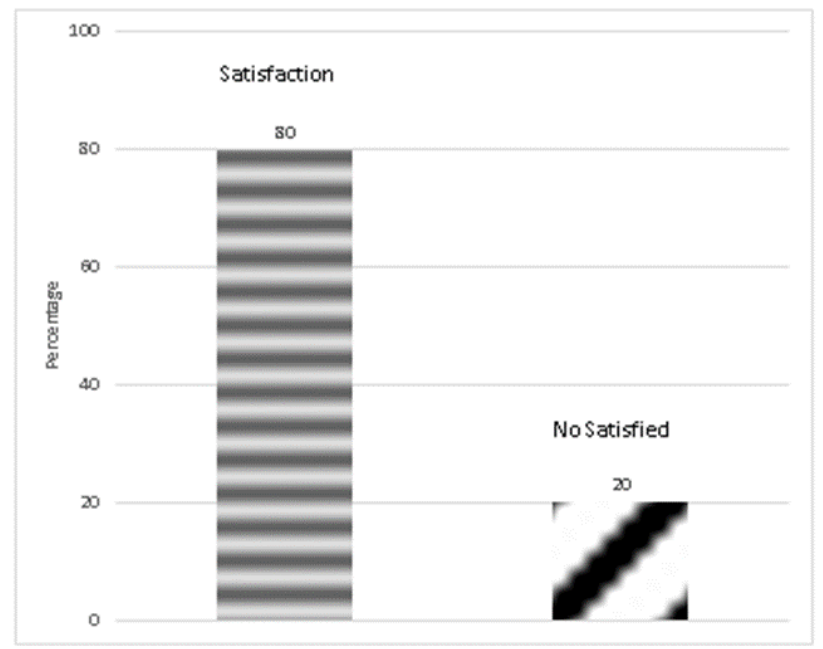

FIGURE 5. Student Satisfaction Level

Based on the data above that most students feel happy with learning to use serious games. But some answered unpleasantly. Let's first review the pleasing results. Students answer that it is fun because it is an innovative learning requirement for facing the industrial revolution 4.0 era. Students feel not bored with the material, and practice questions are explained. Students think that they are playing a game that is on a computer so that the child's own will can absorb the material. Through serious games, students become motivated to learn so they can do the game well.

Next, we review students who answer unpleasant. Based on the results of interviews and direct observation during the learning process, students have difficulty operating computers because some students are not used to using computers.

Then, through serious games, students can operate computers and master the English language in the icon or toolbar because it uses English. So that in this media, three competencies are provided to students, namely learning outcomes in subject matter, computer skills, and English language skills.

\section{SUMMARY}

Based on the explanation above, it can be concluded that the use of serious games as a learning medium is more effective as an additional activity to deepen the concept of light or material being taught. The use of serious games is more effective in learning when compared to using direct knowledge.

\section{ACKNOWLEDGMENTS}

On this occasion, we would like to thank Sultan Ageng Tirtayasa for providing facilities and infrastructure so that this research can be carried out smoothly and according to a predetermined schedule.

\section{REFERENCES}

Astra, IM \& Budi, E 2018, 'The Development of Thermal Expansion Practicum Sets to Improve Science Process Skills of High-School Students', Jurnal Penelitian Dan Pengembangan Pendidikan Fisika, August. 
Berge, M 2016, 'The Role of Humor in Learning Physics : a Study of Undergraduate Students Research in Science Education', https://doi.org/10.1007/s11165-015-9508-4.

Bessarabova, E, Piercy, CW, King, S, Vincent, C, Dunbar, NE, Burgoon, JK, Lee, Y 2016, 'Computers in Human Behavior Mitigating bias blind spot via a serious video game', Computers in Human Behavior', vol. 62, pp. 452-466, https://doi.org/10.1016/j.chb.2016.03.089.

Coninck, KDe, Walker, J, Dotger, B \& Vanderlinde, R 2020, 'Studies in Educational Evaluation Measuring student teachers', self-e ffi cacy beliefs about family-teacher communication: Scale construction and validation, Studies in Educational Evaluation, September 2019, vol. 64, p. 100820, https://doi.org/10.1016/j.stueduc.2019.100820

Creswell, JW 2013, 'Research Design Qualitative, Quantitative, and Mixed Method Approaches'.

Diana, N, Khaldun, I \& Nur, S 2019, 'Improving Students', Performance by Using Science Process Skills i n The High School's Physics Curriculum Grade X in Indonesia, Jurnal Penelitian Dan Pengembangan Pendidikan Fisika, vol. 5, no. 1, pp. 41- 8.

Dong, M 2020, 'Studies in Educational Evaluation Structural relationship between learners , perceptions of a test, learning practices, and learning outcomes: A study on the washback mechanism of a high-stakes test', Studies in Educational Evaluation, October 2018, vol. 64, p. 100824, https://doi.org/10.1016/j.stueduc.2019.100824.

Fischer, E \& Hänze, M 2020, 'Back from " guide on the side " to " sage on the stage " ? E ff ects of teacher-guided and student-activating teaching methods on student learning in higher education', International Journal of Educational Research, March 2019, vol. 95, pp. 26-35, https://doi.org/10.1016/j.ijer.2019.03.001.

Hake, RR 1998, 'Interactive-engagement versus traditional methods: A six-thousand-student survey of mechanics test data for introductory physics courses', American Journal of Physics, vol. 66, no. 1, pp. 64-74, https://doi.org/10.1119/1.18809.

Haryadi, R \& Pujiastuti, H 2019, 'Discovery Learning based on Natural Phenomena to Improve Students', Science Process Skills. Jurnal Penelitian \& Pengembangan Pendidikan Fisika, vol. 5, no. 2, pp. 183-92.

Haryadi, R \& Pujiastuti, H 2019, 'Phet Simulation Software-Based Learning to Improve Understanding Ability in Light Concept', European Union Digital Library, https://doi.org/10.4108/eai.21-112018.2282121.

Haryadi, R \& Pujiastuti, H 2020, 'PhET simulation software-based learning to improve science process skills', Journal of Physics: Conf. Series. https://doi.org/10.1088/1742-6596/1521/2/022017.

Haryadi, R \& Pujiastuti, H 2020, 'The Science Literacy Capabilities Profile Using Guided Inquiry Learning Models', Jurnal Penelitian \& Pengembangan Pendidikan Fisika, vol. 6, no. 1, pp. 81-8.

Haryadi, R \& Pujiastuti, H 2020, 'Use of bungee jumping with stem approach to improve science process skills', Journal of Physics: Conf. Series, https://doi.org/10.1088/17426596/1480/1/012073.

He, H, Han, D, \& Dezert, J 2019, 'Knowledge-Based Systems Disagreement based semi-supervised learning approaches with belief', Knowledge-Based Systems, (xxxx), 105426, https://doi.org/10.1016/j.knosys.2019.105426

Kafai, YB 2018, 'Constructionist visions: Hard fun with serious games. International Journal of ChildComputer Interaction', https://doi.org/10.1016/j.ijcci.2018.04.002.

Kayali, F, Silbernagl, M, Peters, K, Mateus-berr, R, Martinek, D, Lawitschka, A \& Hlavacs, H 2016, 'Design Considerations for a Serious Game for Children after Hematopoietic Stem Cell Transplantation', Entertainment Computing, https://doi.org/10.1016/j.entcom.2016.04.002. 
Khaled, R \& Vasalou, A 2014, 'International Journal of Child-Computer Interaction Bridging serious games and participatory design', International Journal of Child-Computer Interaction, https://doi.org/10.1016/j.ijcci.2014.03.001.

Koponen, IT \& Huttunen, L 2013, 'Concept Development in Learning Physics : The Case of Electric Current and Voltage Revisited', Springer Science+Business Media BV, pp. 2227-254. https://doi.org/10.1007/s11191-012-9508-y.

Kurniawati, A 2018, 'The Development of Authentic Assessment Instrument to Measure Science Process Skill and Achievement based on Students' Performance', Jurnal Penelitian Dan Pengembangan Pendidikan Fisika, 4 May, pp. 65-74.

Lawrence, L, Garber, J, Eva, MH \& Una, OB 2018, 'Constituting, testing and validating the gender learner profiles of serious game participants', pdf. The International Journal of Management Education, vol. 16, p. 205223.

Madani, K, Pierce, TW \& Mirchi, A 2017, 'Serious games on environmental management', Sustainable Cities and Society, vol. 29, pp. 1-11. https://doi.org/10.1016/j.scs.2016.11.007.

Maganty, N, Ilyas, M, Zhang, N \& Sharma, A 2017, 'Patient Education and Counseling Online, gamebased education for melanoma recognition: A pilot study', Patient Education and Counseling, https://doi.org/10.1016/j.pec.2017.11.003.

Malva, L, Leijen, Ä \& Baucal, A 2020, 'Studies in Educational Evaluation Towards measuring teachers' general pedagogical knowledge - A mixed method investigation of a pilot test', Studies in Educational Evaluation, vol. 64, February 2019, p. 100815, https://doi.org/10.1016/j.stueduc.2019.100815.

Merlone, U, Panchuk, A \& Geert, PVan 2019, 'Modeling learning and teaching interaction by a map with vanishing denominators: Fixed points stability and bifurcations R', Chaos, Solitons and Fractals, vol. 126, pp. 253-65. https://doi.org/10.1016/j.chaos.2019.06.008.

Moloney, J, Globa, A, Wang, R \& Roetzel, A 2017, 'Serious games for integral sustainable design : Level 1', Procedia Engineering, vol. 180, pp. 1744-753, https://doi.org/10.1016/j.proeng.2017.04.337.

Ningrum, MV \& Indrasari, W 2019, 'The Validity of Student Worksheet Using Inquiry-Based Learning Model with Science Process Skill Approach for Physics Learning of High School', Jurnal Penelitian Dan Pengembangan Pendidikan Fisika, vol. 5, no. 2, pp. 155-62.

Pasin, F \& Giroux, H 2011, 'Computers \& Education The impact of a simulation game on operations management education', Computers \& Education, vol. 57,no. 1, pp. 1240-254. https://doi.org/10.1016/j.compedu.2010.12.006

Perini, S, Luglietti, R, Margoudi, M, Oliveira, M \& Taisch, M 2018, 'Computers in Industry Learning and motivational effects of digital game-based learning ( DGBL ) for manufacturing education The Life Cycle Assessment ( LCA ) game', Computers in Industry, vol. 102, pp. 40-9, https://doi.org/10.1016/j.compind.2018.08.005.

Pujiastuti, H \& Haryadi, R 2020, 'The Use of Augmented Reality Blended Learning for Improving Understanding of Food Security in Universitas Sultan Ageng Tirtayasa: A Case Study', Jurnal Pendidikan IPA Indonesia T, vol. 9, no.1, https://doi.org/10.15294/jpii.v9i1.21742.

Pujiastuti, H, Utami, R \& Haryadi, R 2020, 'The development of interactive mathematics learning media based on local wisdom and 21st century skills: social arithmetic concept', Journal of Physics: Conference Series, https://doi.org/10.1088/1742-6596/1521/3/032019.

Putnik, G, Stief, P, Dantan, J, Etienne, A, Siadat, A, \& Putnik, G 2019, 'ScienceDirect ScienceDirect ScienceDirect infrastructure in Social Learning material material infrastructure Social Education: An implementation model Education: An implementation model A new methodology to analyze the functional and physical architecture of existing products for an assembly oriented product family identification', Procedia CIRP, vol. 84, pp. 215-18. https://doi.org/10.1016/j.procir.2019.07.003. 
Radianti, J, Lazreg, MBen \& Granmo, O 2015, 'Engineering Applications of Arti fi cial Intelligence Fire simulation-based adaptation of SmartRescue App for serious game : Design, setup and user experience \$', Engineering Applications of Artificial Intelligence, vol. 46, pp. 312-25. https://doi.org/10.1016/j.engappai.2015.06.012.

Riemer, V \& Schrader, C 2015, 'Learning with quizzes, simulations, and adventures: Students' attitudes, perceptions and intentions to learn with different types of serious games', Computers \& Education, https://doi.org/10.1016/j.compedu.2015.05.003.

Shepherd, MD \& van de Sande, CC 2014, 'Reading mathematics for understanding-From novice to expert', Journal of Mathematical Behavior, vol. 35, pp. 74-86, https://doi.org/10.1016/j.jmathb.2014.06.003.

Steins, G, Behravan, B \& Behnke, K 2020, 'Studies in Educational Evaluation Is resistance futile? Teachers ' viewpoints about school inspection - Taking practioners ' perspectives into account', Studies in Educational Evaluation, vol. 64, April 2019, p. 100825, https://doi.org/10.1016/j.stueduc.2019.100825.

Sterkenburg, PS \& Vacaru, VS 2018, 'The effectiveness of a serious game to enhance empathy for care workers for people with disabilities: A parallel randomized controlled trial', Disability and Health Journal, https://doi.org/10.1016/j.dhjo.2018.03.003.

Suttie, N, Louchart, S, Lim, T, Macvean, A, Westera, W, Djaouti, D \& Brown, D 2012, 'In Persuit of a 'Serious Games Mechanics', Procedia - Procedia Computer Science, vol. 15, pp. 314-15, https://doi.org/10.1016/j.procs.2012.10.091.

Young, H, Moore, KC \& Ibrahim, H 2019, 'Reasoning within quantitative frames of reference: The case of', Journal of Mathematical Behavior, vol. 53, December 2017, pp. 81-95, https://doi.org/10.1016/j.jmathb.2018.06.001. 
